\title{
Overview of Treatment for Obstructive Sleep Apnea in Adults
}

\author{
Jun-Sang Sunwoo ${ }^{1}$, Kwang Ik Yang ${ }^{2}$ \\ ${ }^{1}$ Department of Neurology, Soonchunhyang University College of Medicine, Seoul Hospital, Seoul, \\ ${ }^{2}$ Sleep Disorders Center, Department of Neurology, Soonchunhyang University College of Medicine, Cheonan Hospital, Cheonan, Korea
}

\section{성인 폐쇄수면무호흡의 치료 개괄}

선우준상 ${ }^{1}$, 양광익 ${ }^{2}$

순천향대학교 의과대학 서울병원 신경과학교실, ${ }^{1}$ 순천향대학교 의과대학 천안병원 신경과학교실 수면장애센터 ${ }^{2}$

\author{
Received June 2, 2017 \\ Revised June 15, 2017 \\ Accepted June 16, 2017 \\ Address for correspondence \\ Kwang Ik Yang, MD, PhD \\ Sleep Disorders Center, \\ Department of Neurology, \\ Soonchunhyang University \\ Cheonan Hospital, 31 Soonchun- \\ hyang 6-gil, Dongnam-gu, \\ Cheonan 31151, Korea \\ Tel: +82-41-570-2290 \\ Fax: $+82-41-592-3810$ \\ E-mail: neurofan@schmc.ac.kr
}

Obstructive sleep apnea (OSA) is a common disorder characterized by obstructive apneas, hypopneas, and respiratory effort related arousals during sleep. Treatment of OSA is important because untreated patients have potential adverse clinical outcomes, such as excessive daytime sleepiness, metabolic dysfunction, cardiovascular disease, and mortality. Therefore, OSA should be considered as a chronic disease that requires long-term and multidisciplinary care. Positive airway pressure (PAP) therapy is the mainstay of treatment for OSA in adults. Alternative therapies include oral appliance, behavioral modification, and upper airway surgery. The treatment of OSA in adults is reviewed here with focus on PAP therapy.

J Sleep Med 2017;14(1):1-9

Key Words: Obstructive sleep apnea, Positive airway pressure, Oral appliance, Behavioral therapy.

\section{서 론}

폐쇄수면무호흡(obstructive sleep apnea, OSA)은 성인에 서 2 4\%의 발병률을 보이고 나이가 들수록 증가하며, 국내 역시 남자 $4.5 \%$, 여자 $3.2 \%$ 비슷한 유병률을 보이는 흔한 수 면관련호흡장애(sleep related breathing disorder)로서, ${ }^{1,2}$ 수 면다원검사를 통한 국제수면장애분류(International Classification of Sleep Disorders-3) 진단 기준에 의해 진단을 내 린다. 수면다원검사에서 호흡장애지수[respiratory disturbance index $(\mathrm{RDI})=($ 무호흡+저호흡+호흡노력각성 $)$ 의 횟수/ 수면 시간]가 5 이상이면서 이와 관련한 증상이 있는 경우로 정의한다. 관련 증상에는 주간졸림, 피로, 자고 나도 개운치 않은 불면증과 같은 증상과 코골이 및 수면무호흡 관찰이 포 함되며, 이 중 하나만 있으면 진단할 수 있다. 또한, 환자에게 관련 증상이 없어도 수면호흡장애지수가 15 이상이면 폐쇄 수면무호흡장애로 정의한다. ${ }^{3}$ 폐쇄수면무호흡의 정도는 수

This is an Open Access article distributed under the terms of the Creative Commons Attribution Non-Commercial License (http://creativecommons.org/licenses/by-nc/4.0) which permits unrestricted non-commercial use, distribution, and reproduction in any medium, provided the original work is properly cited.
면다원검사를 통해 시간당 무호흡-저호흡 발생 횟수(apneahypopnea index, AHI)에 따라 정상 $(\mathrm{AHI}<5)$, 경도 $(5 \leq \mathrm{AHI}$ $<15)$, 중등도 $(15 \leq \mathrm{AHI}<30)$, 중증 $(\mathrm{AHI} \geq 30)$ 으로 나뉘며, $\mathrm{RDI}$ 와 혼용하여 사용하기도 한다. 폐쇄수면무호흡은 수면 중 상기도의 완전 또는 부분적 폐쇄로 인하여 공기 흐름의 제한, 정상 수면의 단절, 산소 포화도 감소, 고탄산혈증, 흥곽 내 압력 변동과 교감신경 활성 증가 등을 야기시킴으로써 주 간 삶의 질을 저하시키며, 인지 기능 저하 및 심뇌혈관계통과 대사 장애의 원인이 된다. 4.5 적절한 폐쇄수면무호흡 치료는 삶의 질 개선과 더불어 이러한 동반 질환의 발생을 낮출 수 있다. ${ }^{6}$ 폐쇄수면무호흡은 만성 질환으로 접근해야 하며 장기 간 관리 및 다양한 치료법이 적용된다. ${ }^{7}$ 이에는 폐쇄수면무 호흡을 악화시킬 수 있는 요소들을 피하는 행동 조절, 중재 적 치료로서 구강장치 및 양압기와 수술적 접근이 제시된다. 본문에서는 성인 폐쇄수면무호흡의 치료에 대해 문헌고찰 과 함께 소개하고자 한다. 본문에서 사용되는 권고수준은 American Academy of Sleep Medicine(AASM) 기준을 따른다 (Table 1). 


\section{본 론}

\section{양압기(positive airway pressure, $\mathrm{PAP}$ )}

양압기란 양압을 발생하는 기계로부터 압력이 튜브 및 마 스크를 통해 상기도로 전달됨으로써 상기도가 막히는 것을 방지하는 방법이다. 1981년 Sullivan 등이 처음으로 고안한 지속양압기(continuous positive airway pressure, $\mathrm{CPAP}$ )는 부피가 상당히 크고 무거우며 시끄러웠다. ${ }^{8}$ 하지만 이후 양압 기가 지속적으로 발전하여 과거보다 작고 가벼우며 소음 면 에서도 조용해졌으며, 현재 폐쇄수면무호흡의 대표적 치료 법이다. 양압기는 압력을 전달하는 방법에 따라 4가지 종류 가 있다. 지속적으로 한 가지 고정된 양압을 전달하는 CPAP, 호기 양압(expiratory PAP, EPAP)과 이보다 높은 압력인 흡 기 양압(inspiratory PAP, IPAP)의 다른 두 양압을 전달하는 bilevel PAP(BPAP), 자동적으로 CPAP, BPAP(IPAP/EPAP) 를 조절하는 자동양압기 (auto-titrating positive airway pressure, APAP)가 있으며, 마지막으로 울혈성 심부전 환자에게 서 관찰될 수 있는 체인-스톡스 호흡(Cheyne-Stokes breathing) 같은 중추수면무호흡(central sleep apnea)에 적용할 수 있는 adaptive servo-ventilation은 자동적으로 압력 이외에 적당한 환기(ventilation)를 유지시켜준다. ${ }^{9}$

\section{행동 요법(behavioral strategies)}

폐쇄수면무호흡의 행동 요법에는 체중 감량, 체위 요법, 그리고 악화 인자 회피 등이 있다. 그중 체중 감량의 폐쇄수 면무호흡 치료 효과는 여러 연구를 통해서 잘 알려져 있다. 전향적 코호트 연구로 4년 간격으로 수면다원검사를 추적한 결과, $10 \%$ 의 체중 증가는 $\mathrm{AHI}$ 를 약 $32 \%$ 증가시키고 중등도 이상의 폐쇄수면무호흡 발생 위험을 약 6 배 증가시키는 반 면, $10 \%$ 의 체중 감소는 $\mathrm{AHI}$ 를 약 $26 \%$ 감소시키는 효과를 보였다. ${ }^{10}$ 또한, 비만 중년 남성을 대상으로 인지행동요법을 이용한 체중 감량을 시행한 결과 24개월째 평균 $12.6 \mathrm{~kg}$ (기본 체중의 9\%)의 체중이 감소되었고, oxygen desaturation index (ODI, 산소포화도가 $4 \%$ 이상 감소하는 이벤트의 시간당 평 균 발생 건수)의 $50 \%$ 이상 감소가 $42 \%$ 에서 관찰되었다. ${ }^{11}$ 또
한 체중 감량의 정도와 $\mathrm{ODI}$ 감소 정도는 유의한 상관관계(상 관계수 0.75)를 보였고, 이는 체중 감량이 폐쇄수면무호흡의 호전에 효과적이라는 결과를 뒷받침한다. 따라서 체중 감량 은 모든 과체중 폐쇄수면무호흡 환자에게 권고되어야 한다 (guideline). ${ }^{12}$ 하지만, 체중 감량만으로 폐쇄수면무호흡의 완 치를 기대하기는 어렵고, 또한 상대적으로 체중 감량의 치료 효과가 뒤늦게 나타나는 점을 고려하면, 체중 감량은 단독 치 료보다는 양압기 등 일차적인 치료법과 병행하는 것이 좋다 (option). 그리고 충분한 정도의 체중 감량에 도달했을 때에 는, 수면다원검사 추적 검사를 실시하여 양압기가 계속 필요 한지 혹은 양압 수준의 조정이 필요한지에 대한 평가를 실시 해야 한다(standard). ${ }^{7}$

폐쇄수면무호흡을 악화시킬 수 있는 위험 인자를 피하는 것 역시 행동 요법의 중요한 부분이다. 첫 번째로, 알코올이 폐쇄수면무호흡을 악화시키는 사실은 잘 알려져 있다. 알코올 섭취는 단순 코골이(primary snoring) 환자에서 수면 중 무호 흡을 유발하고, 또한 수면무호흡 환자들에서는 무호흡의 빈 도와 중증도를 악화시킨다. ${ }^{13}$ 게다가 알코올은 폐쇄수면무호 흡 환자의 주간 졸림증을 더욱 악화시키는 영향이 있다. 따라 서, 모든 폐쇄수면무호흡 환자는 음주를 하지 않는 것이 권 고되며, 완전한 금주가 어려울 경우는 음주량을 제한하고 취 침 전 두 시간 이내에는 음주를 피하도록 한다. ${ }^{14}$ 또한, 폐쇄수 면무호흡 환자에서 벤조디아제핀 계열의 수면-진정제는 무 호흡을 악화시킬 수 있기 때문에 신중히 사용해야 한다. ${ }^{14}$ 흡 연은 수면의 질을 악화시킬 뿐 아니라 폐쇄수면무호흡의 위 험인자로 작용한다. ${ }^{15}$ 이는 흡연이 점막의 부종을 유발하고 상 기도 저항을 증가시키기 때문으로 여겨진다. 비록 금연이 수 면무호흡 자체를 호전시키는 효과는 크지 않겠으나, 흡연이 전신 장기에 미치는 악영향을 고려하여 금연은 모든 폐쇄수 면무호흡 환자에게 반드시 권고되어야 한다.

\section{체위 요법(position therapy)}

수면 중 체위는 기도의 크기와 개방성에 영향을 미치며 앙 와위(supine) 자세에서 상기도의 단면적은 감소하게 된다. ${ }^{16}$ 따라서, 많은 환자에서 수면 중 무호흡은 비앙와위(non-su-

Table 1. American Academy of Sleep Medicine level of recommendation

\begin{tabular}{cc}
\hline Term & Definition \\
\hline Standard & $\begin{array}{c}\text { This is a generally accepted patient-care strategy that reflects a high degree of clinical certainty. The term standard generally } \\
\text { implies the use of Level } 1 \text { Evidence, which directly addresses the clinical issue, or overwhelming Level } 2 \text { Evidence. }\end{array}$ \\
Guideline & $\begin{array}{c}\text { This is a patient-care strategy that reflects a moderate degree of clinical certainty. The term guideline implies the use } \\
\text { of Level } 2 \text { Evidence or a consensus of Level } 3 \text { Evidence. }\end{array}$ \\
Option & $\begin{array}{l}\text { This is a patient-care strategy that reflects uncertain clinical use. The term option implies insufficient, inconclusive, } \\
\text { or conflicting evidence or conflicting expert opinion. }\end{array}$ \\
\hline
\end{tabular}


pine) 자세보다 앙와위 자세에서 더욱 빈번하게 발생한다. ${ }^{17}$ 체위 요법은 수면 중 비앙와위 자세를 유지하는 방법으로, 앙 와위 $\mathrm{AHI}$ 에 비해서 비앙와위 $\mathrm{AHI}$ 수치가 상대적으로 낮은 폐쇄수면무호흡 환자의 이차적 혹은 부가적 치료로 활용될 수 있다(guideline). ${ }^{12}$ 이런 체위성 폐쇄수면무호흡 환자를 대상으로 체위 요법을 시행한 결과, AHI 수치가 평균적으로 17.9에서 9.5로 감소하는 유의한 효과를 보였다. ${ }^{18}$ 하지만 모 든 환자가 비앙와위 자세에서 $\mathrm{AHI}$ 가 정상 수준까지 감소하 지는 않기 때문에, 체위 요법을 일차 치료로 시작하기 전에 는 반드시 수면다원검사를 실시하여 체위 변화에 따른 폐쇄 수면무호흡 치료 정도를 평가해야 한다(consensus)..$^{19}$ 그리 고 체위 요법을 시작할 때에는 비앙와위 자세를 유지하도록 도와주는 기구(알람, 베개, 테니스공 등)를 활용하는 것이 좋 다(consensus). ${ }^{7}$

\section{구강 내 장치(oral appliance)}

구강 내 장치는 상기도의 단면적을 증가시키고 상기도 근 육의 긴장도를 호전시킴으로써 수면 중 상기도 개방성을 호 전시키는 효과가 있다. ${ }^{20}$ 아래턱 재배치 장치(mandibular repositioning appliance)는 윗니와 아랫니 모두를 커버하며 아 래턱의 위치가 평상시보다 전진되도록 유지한다. 혀 고정 장치 (tongue retraining devices)는 아래턱 위치의 변화 없이 혀만 앞쪽으로 재배치하는 방식이다. 치료 성공을 AHI 10 이하 감 소로 정의했을 때, 중등도의 폐쇄수면무호흡 환자에서 구강 내 장치 치료 성공률은 약 $52.6 \%$ 정도로 보고된다. 폐쇄수면 무호흡의 중증도별 구강 내 장치 치료효과를 분석한 연구에 서, 경도 환자군은 약 $81 \%$, 중등도 환자군은 $60 \%$, 중증 환자 군은 $25 \%$ 의 치료 성공률을 보였다. ${ }^{21}$ 구강 내 장치의 과다 졸 림증을 개선하는 효과는 지속양압기와 동등한 수준이지만, $\mathrm{AHI}$ 감소 효과 측면에서는 지속양압기만큼 효과적이지 않 다. 따라서, 경도-중등도의 폐쇄수면무호흡 환자 중에서 양 압기보다 상대적으로 구강 내 장치를 선호하는 경우, 지속양 압기 치료에 반응하지 않거나 지속양압기 사용에 적합하지 않은 경우, 또는 지속양압기나 행동 요법에 실패한 경우가 구 강 내 장치의 적응증에 해당한다(guideline). ${ }^{22}$ 구강 내 장치 는 단순 코골이 치료에 적합하며, 특히 체중 감량이나 체위 교정 등의 방법이 효과가 없거나 불가능한 경우에 구강 내 장 치의 적응증이 된다(guideline). 중증 폐쇄수면무호흡 환자 는 먼저 지속양압기 치료를 시도해야 하는데, 이는 상기 환 자군에서 구강 내 장치보다 지속양압기의 치료 효과가 더욱 월등하기 때문이다(guideline). ${ }^{22}$ 따라서, 구강 내 장치를 시 작하기 전에 반드시 폐쇄수면무호흡 여부에 대한 평가가 되 어야 하고, 적절한 치료 방침을 결정하기 위해서 폐쇄수면무
호흡의 중증도를 확인해야 한다(standard). ${ }^{22}$ 아래턱 재배치 장치는 치아가 건강해야 하고, 턱관절(temporomandibular joint)의 장애가 없어야 하며, 장치를 뺐다 꼈다 할 수 있는 적 절한 손놀림이 가능해야 한다. 혀 고정 장치는 아래턱 재배치 장치에 적합하지 않은 환자에서 활용될 수 있다. 폐쇄수면무 호흡 치료 목적으로 구강 내 장치를 사용하는 경우 처음 1 년 동안은 6개월 간격으로, 이후로는 1년에 한 번 간격으로 치 과 진료가 필요하다(guideline). 이는 치료 유지 여부를 평가 하고, 장치의 이상이나 치아의 교합 이상 및 폐쇄수면무호흡 증의 악화 여부 등을 확인하기 위함이다.?

\section{지속양압기(CPAP/BPAP) 권고 사항}

$\mathrm{AASM}$ 의 지속양압기에 대한 권고 사항은 다음과 같다. 적 응증은 1) 중등도 내지 중증 폐쇄수면무호흡(standard), 2) 경 증 폐쇄수면무호흡(option), 3) 주간졸림을 호소하거나 주간 삶의 질 향상을 위한 경증 이상의 폐쇄수면무호흡(standard), 4) 고혈압이 동반된 폐쇄수면무호흡에서 혈압 조절을 위한 부수적 요법(option) 등이다. 양압기 사용의 순응도를 높이 기 위해서는 1) 양압기 사용에 대한 객관적 모니터링으로 순 응도 평가(standard), 2) 제대로 훈련된 관리를 통해 양압기 의 효과 및 순응도를 정기적으로 추적 관찰이 필요한데 특 히, 첫 수주간에는 면밀 추적 관찰을 통해 처음 양압기 사용 자들의 적응에 도움을 주고, 이후 장기적으로 순응도를 유지 하기 위해서 마스크 사용 및 양압기 성능, 사용 중 불편감 등 에 대한 지속적이고 정기적 추적 관찰이 필요(standard), 3) 온 열 및 가습이 가능한 양압기가 순응도를 향상(standard), 4) 양압기 필요성에 대한 체계화된 환자 교육이 순응도를 향상 (standard)시킬 수 있다(Table 2). 또한, 양압기는 비교적 안 전하고 부작용은 미미하거나 가역적이다(standard). 비염, 마스크를 통한 공기 유출, 안면 피부염이 종종 발생할 수 있 으며 이명 및 호흡곤란 등이 드물게 나타날 수 있다(Table 3). ${ }^{23}$ $\mathrm{CPAP}$ 사용에 높은 압력이 필요하고 이로 인해 호기 시 불 편함을 느끼는 경우 및 중추저환기가 나타나면 $\mathrm{BPAP}$ 를 적 용할 수 있다(guideline). BPAP는 주간 고탄산혈증을 동반 한 제한폐질환 및 저환기증후군에 적용할 수 있다(option).

\section{양압 적정 (PAP titration)}

양압 적정의 목적은 폐쇄 호흡 관련 사건인 무호흡, 저호 흡, 호흡노력각성, 그리고 코골이를 제거할 수 있는 수준의 압력을 얻는 것이다. 2007년 4월에 'The AASM Board of Directors'는 양압 적정에 대한 권고 개발을 승인하였으며 'PAP Titration Task Force'를 구성하였다. 이전까지 약 4반 세기 동안 수기 양압 적정이 수행되어 왔지만 표준화된 지 
Table 2. Components of patient education contents for patient with OSA

Findings of sleep study, severity of OSA

Pathophysiology of OSA

Explanation of natural course of OSA and associated disorders

Risk factor identification, explanation of exacerbating factors, and risk factor modification

Genetic counseling when indicated

Treatment options

What to expect from treatment

Outline the patient's role in treatment, address their concerns, and set goals

Consequences of untreated OSA

Drowsy driving/sleepiness counseling

Patient quality assessment and other feedback regarding evaluation

OSA: obstructive sleep apnea

침이 없었으며, 이런 부재로 인해 각 검사실마다 다른 프로 토콜에 의존하였고 표준화된 양압 적정 지침의 필요성을 느 끼게 되었다. ${ }^{24}$ 2008년 'Positive Airway Pressure Titration Task Force of the AASM'에 의해 폐쇄수면무호흡 환자에 게서 최적의 양압 적정을 위한 가이드라인이 제시되었다. ${ }^{9}$

\section{지속양압기 치료의 효과}

양압기 사용이 주간졸림 개선, 혈압강하, 인슐린 민감도 개 선, 고혈압 및 심혈관계 질환 감소, 뇌경색 환자의 신경학적 증상 개선과 교통사고 발생 감소에 효과를 보인 다양한 무 작위대조군 연구가 있다. 주간졸림 개선 및 혈압 강하에 대한 4주간의 무작위대조군 연구에서 Epworth Sleepiness Scale (ESS)을 통한 주간졸림은 sub-therapeutic 수준의 압력에서 도 개선을 보였지만, 다중수면잠복기검사(multiple sleep latency test, MSLT)에서는 개선을 보이지 않았다. 하지만 therapeutic 압력 수준의 양압 치료에서는 ESS 및 MSLT에 서 의미 있는 개선을 보여 주었다. ${ }^{25}$ 이는 양압기 사용이 주 간졸림에 대한 위약 효과 외에 객관적인 졸림 개선에 효과 가 있음을 시사하였다. 또한 적정 압력 양압기 사용군에서 의미 있는 24 시간 평균 혈압 감소를 보였다 $(2.5 \mathrm{vs} .-0.8 \mathrm{~mm}$ $\mathrm{Hg}, p=0.013){ }^{26} 50$ 명의 내당능 장애를 동반한 중등도 및 중 증(AHI 15 이상) 폐쇄수면무호흡 환자를 대상으로 $\mathrm{CPAP}$ 사용군과 sham $\mathrm{CPAP}$ 사용군을 비교한 무작위대조군 연구 에서 8주째 2-시간 경구혈당내성 및 인슐린 민감도를 통한 내당능 변화에서 $\mathrm{CPAP}$ 사용 치료 후 내당능 장애의 호전을 보이지는 않았다. 하지만 AHI 30 이상의 폐쇄수면무호흡 환 자에서는 sham CPAP 사용군과 비교하여 CPAP 사용군에 서 인슐린 민감도가 $13.3 \%$ 호전 $(p<0.001), 2$-시간 인슐린
Table 3. Possible PAP-related adverse effect

\begin{tabular}{|c|}
\hline Interface \\
\hline Mask leak \\
\hline Skin abrasion/ulceration \\
\hline Mask allergy \\
\hline Conjunctivitis/sore eyes \\
\hline Dermatitis/facial irritation \\
\hline Claustrophobia \\
\hline Pressure-related \\
\hline Rhinitis \\
\hline Rhinorrhea \\
\hline Sneezing \\
\hline Desiccation \\
\hline Sinusitis \\
\hline Headache \\
\hline Epistaxis \\
\hline Otitis/ear pain \\
\hline Air swallowing/aspiration \\
\hline Belching \\
\hline Mouth leak (dry mouth) or mask leak \\
\hline Pressure intolerance \\
\hline Suffocation or difficulty exhaling \\
\hline Tinnitus \\
\hline Aerophagia \\
\hline Pneumoencephalus \\
\hline Central sleep apnea \\
\hline Prolonged oxyhemoglobin desaturation \\
\hline Equipment related \\
\hline Noise \\
\hline Smell \\
\hline Tubing condensation \\
\hline Cumbersome equipment \\
\hline Spousal intolerance \\
\hline Equipment maintenance and cleaning \\
\hline General \\
\hline Periodic limb movement \\
\hline Anxiety \\
\hline Insomnia \\
\hline Headache \\
\hline Chest discomfort \\
\hline Fatigue/feeling tired \\
\hline
\end{tabular}

PAP: positive airway pressure

수치가 $28.7 \%$ 감소 $(p=0.002)$ 를 보였다. ${ }^{27} 54$ 명의 관상동맥협 착을 동반한 AHI 15 이상 폐쇄수면무호흡 환자를 대상으로 평균 86.5개월 동안 심혈관질환으로 인한 사망, 급성관상동 
맥증후군, 심부전 발생 등을 추적 관찰한 전향 연구에서 $\mathrm{CPAP}$ 를 사용한 군에서 의미 있는 감소를 보였다(hazard ratio $0.24 ; p<0.01){ }^{28} 24$ 명의 심부전을 동반한 폐쇄수면무호흡 환자를 대상으로 시행한 연구에서, 약물 치료와 함께 CPAP 치료를 병행한 군에서는 1 개월 후 현저한 주간 수축기 혈압 저하(126 $\pm 6 \mathrm{~mm} \mathrm{Hg}$ vs. $116 \pm 5 \mathrm{~mm} \mathrm{Hg}, p=0.02)$, 심박수 저 하(68 \pm 3 vs. $64 \pm 3$ beats per minute, $p=0.007)$ 와 좌심실 구 혈률 호전(25.0 2.8 to $33.8 \pm 2.4 \%, p<0.001)$ 을 보였지만 약물 치료만 시행한 군에서는 유의한 변화가 없었다. ${ }^{29} 723$ 명 의 주간졸림증이 없는 $\mathrm{AHI} 20$ 이상의 폐쇄수면무호흡 환자 를 대상으로 고혈압과 심혈관질환 발생을 평균 4년 추적 관 찰한 무작위대조군 연구에서 전체 CPAP 사용군에서는 유 의한 감소를 보이지 못했지만, $\mathrm{CPAP}$ 를 하루 4시간 이상 사 용한 군만 분석하였을 때는 유의한 감소를 보였다 $(p=0.04) .{ }^{30}$ 이는 폐쇄수면무호흡 환자에게 $\mathrm{CPAP}$ 를 하루 4시간 이상 사 용하도록 권장하는 근거가 될 수 있다. AHI 20 이상의 뇌경 색 환자를 대상으로 71 명의 $\mathrm{CPAP}$ 사용군과 치료하지 않은 69 명의 대조군을 2년간 관찰한 연구에서, $\mathrm{CPAP}$ 사용군에서 뇌졸중 1개월 후 신경학적 호전을 보인 환자가 유의하게 높았 으며(Rankin Scale 90.9 vs. $56.3 \% p<0.01$ ), 심혈관질환 발 생까지 시간도 길게 나타났지만(14.9 vs. 7.9 개월, $p=0.044$ ), 생 존율과 삶의 질에서는 두 군 간 차이를 보이지 않았다. ${ }^{31} 264$ 명 의 정상, 377명의 단순 코골이, 403 명의 경증 및 중등도 폐쇄 수면무호흡, 235 명의 증증 폐쇄수면무호흡, 372명의 CPAP 를 사용하는 폐쇄수면무호흡 환자군을 대상으로 치명적 및 비치명적 심혈관질환 발생(발생 건/100명/년)을 평균 10.1년 동안 관찰한 연구에서, 중증 폐쇄수면무호흡 환자군에서 높 은 치명적 발생(1.06/100명/년)과 비치명적 발생(2.13/100 명/년)을 보여 다음과 같은 군에 비해 유의하게 높았다; 정상 군(0.3, $p=0.012 ; 0.45, p<0.0001)$, 단순 코골이 $(0.34, p=0.0006$; $0.58, p<0.0001)$, 경증 및 중등도 폐쇄수면무호흡 $(0.55, p=$ $0.02 ; 0.89, p<0.001)$, CPAP 치료군( $0.35, p=0.008 ; 0.64, p<$ 0.001). 다변량 분석에서 중증 폐쇄수면무호흡 군에서 높은 심혈관질환 발생률을 보였으며[치명적: odds ratio(OR) 2.87, 95\% confidence interval(CI) 1.17-7.51, 비치명적: OR 3.17, 95\% CI 1.12-7.51], CPAP 사용군을 포함한 다른 군에서는 의 미 있는 치명적 및 비치명적 심혈관 질환 발생을 보이지 않 았다. ${ }^{4}$ 급성 뇌경색 환자 중 APAP 사용군 31 명과 대조군 24 명을 대상으로 한 무작위대조군 연구에서, APAP 사용군에 서 30일 후 유의한 National Institutes of Health Stroke Scale 개선을 보였다(-3.0 vs. $-1.0 ; p=0.03) .{ }^{32} 210$ 명의 폐쇄수면무 호흡 환자에서 교통사고 발생(교통사고/명/년)이 대조군에 비해 높았으며(0.18 \pm 0.29 vs. $0.06 \pm 0.17, p<0.001)$, CPAP
사용군과 대조군을 3년간 추적 관찰한 연구에서 CPAP 사용 군에서 교통사고 발생이 유의하게 감소하였지만 $(0.18 \pm 0.29$ to $0.06 \pm 0.17, p<0.001)$, 같은 기간 대조군에서는 교통사고 발생률의 변화가 없었다 $(0.06 \pm 0.17$ to $0.07 \pm 0.18, p=$ not significant). 따라서 두 군 간 교통사고 발생 변화는 유의한 차이가 있었다 $(p<0.001){ }^{33}$

\section{자동양압기(APAP) 권고 사항}

위에서 언급한 바와 같이 양압 적정을 위해서는 검사실 내에서 수면다원검사 감시하에 각 수면 단계 및 수면 중 환 자의 자세에 따른 폐쇄 호흡 사건을 감시하고, 비정상 호흡 사건을 제거하기 위해 수동으로 압력을 조절한다. 즉, 숙련된 수면 기사의 감시 및 적정 검사 전에 마스크 착용과 공기 유 출에 대한 중재가 필요하며, 원활한 적정 검사를 위해 양압 기의 첫 대면을 위한 준비가 필요하다. 고로 검사 비용, 불충 분한 적정이 이루어졌을 경우, 반복 검사로 인한 불편감, 자 신의 침실과 다른 검사실 환경에 따른 편차, 이로 인한 적정 된 압력의 적합성 여부, 시간이 지나면서 나타나는 체중 및 동반된 내과적 조건의 변화에 따른 적정 압력의 변화 가능 성, ${ }^{34}$ 렘단계와 비렘단계, 앙와위 자세와 비앙와위 자세와 같 이 수면 단계 및 자세에 따른 각각 다른 압력이 적정될 수 있 다. 35,36 이런 점을 고려한다면 좀 더 효과적이고 양압 적정 검 사의 간편성과 상황에 따른 고정된 압력이 아닌 변화하는 압 력을 전달할 수 있는 장비에 대한 요구가 APAP 발전에 영 감을 불러일으켰다. $\mathrm{APAP}$ 는 코골이 진동, 공기 흐름을 통한 무호흡, 저호흡 및 flow contour, 압력 변동, 상기도 저항 측정 센서를 통한 되먹임을 통해 치료 압력을 변화시킨다. 2004년 APAP 처방에 대한 미국 'National Survey'에 의하면 전체 처방되는 양압기 중에서 $4 \%$ 가 $\mathrm{APAP}$ 이다. 이후 $\mathrm{APAP}$ 에 대 한 타당성 및 신뢰성에 대한 다양한 연구가 진행되고 있으며, APAP 사용이 증가하고 있는 추세다. 36,37 그럼에도 불구하고, 현재까지는 검사실 내에서 수면다원검사 감시하의 CPAP/ $\mathrm{BPAP}$ 수기 적정이 최적 압력 결정에 있어서 표준이라 할 수 있다. AASM에서는 다음과 같은 경우 $\mathrm{APAP}$ 를 추천하지 않는다(standard). 1) 폐쇄수면무호흡 진단 목적, 2) 울혈심 부전, 만성폐쇄폐질환, 폐쇄수면무호흡 및 기타 질환에 의해 수면 중 동맥 내 산소포화도가 저하되는 경우, 3) 중추수면무 호흡, 4) 분할수면검사(split night study). APAP를 사용하는 경우는 1) 중등도 및 중증 폐쇄수면무호흡 환자에서 $\mathrm{CPAP}$ 사용을 위한 고정 압력을 얻기 위해 수면다원검사 감시하에 서 시행(guideline), 2) 동반 질환 없는 중등도 및 중증 폐쇄 수면무호흡 환자에서 CPAP 사용을 위한 고정 압력을 얻기 위해 수면다원검사 감시 없이 사용할 수 있다(option). APAP 
를 사용하는 경우는 효과 및 안전, 순응도를 정기적으로 관찰 하도록 하고, 폐쇄수면무호흡 증상이 해결 되지 않으면 검사 실에서 수면다원검사 감시하에서 양압 적정을 하도록 권고 한다(standard). ${ }^{38}$

\section{자동 및 지속양압기의 효과 비교}

양압기 순응도, 주간졸림 개선, AHI 개선에 대한 APAP과 $\mathrm{CPAP}$ 사용의 무작위비교 연구에 대한 메타분석에서 두 군 간의 의미 있는 차이는 보이지 않았다. ${ }^{39}$ 이 분석은 9 개 연구 로서 총 282명을 비교하였는데, 12 내지 24주 관찰 연구는 한 개였으며, 대부분 3 주에서 8 주간의 짧은 기간 비교 연구로 서 장기간 APAP 사용 순응도 및 증상 개선을 비교하는 데 한계가 있었다. 24개 무작위비교 연구에 대한 메타분석에서 $\mathrm{APAP}$ 이 CPAP에 비해 하루 11분간 더 사용하였으며 ESS, 점수가 0.5 점 낮은 효과를 보였고 $\mathrm{CPAP}$ 사용군에서 최소산 소포화도가 $1.3 \%$ 향상되는 효과를 보였다. 하지만 연구 질 평 가에서 $\mathrm{A}$ 에 해당하는 두 연구에서는 순응도 및 주간졸림 개 선에서 두 군 간의 차이를 보이지는 않았다. ${ }^{40}$ 이 메타분석에 서 분석한 연구들 역시 짧은 기간 관찰 연구였으며, 순응도 내지 주간졸림의 개선이 통계적으로 유의한 차이는 보였더 라도 임상적 유용성은 명확하지 않았다. 더욱이 의미 있는 동 반 질환은 배제된 환자를 대상으로 하였다. 연구 목적이 폐
쇄수면무호흡과 연관된 고혈압, 심혈관계 질환, 뇌졸중, 대 사증후군, 우울 및 사망과 같은 의미 있는 관찰 항목의 발생 률에 대한 APAP 연구는 없었다. 31명의 중증 폐쇄수면무호 흡 환자의 3 개월 무작위비교 연구에서 $\mathrm{APAP}$ 사용군이 $\mathrm{AHI}$ 및 주간졸림 측면에서 $\mathrm{CPAP}$ 사용군과 마찬가지로 개선을 보 임으로써, 두 군 간의 차이는 없었으나 수축기 및 이완기 혈 압 감소, 인슐린 저항성 감소 측면에서는 CPAP 사용군에서 와 같은 개선 효과를 보이지는 않았다. ${ }^{41} \mathrm{APAP}$ 의 유용성 검 증을 위해서는 다수를 대상으로 한 장기간 연구를 통한 순 응도 및 심혈관질환과 같은 만성 질환 발생에 대한 좀 더 나 은 연구가 필요하다 할 수 있다.

\section{장기적 관리}

폐쇄수면무호흡 환자에서 양압기 순응도를 높이기 위해 서는 환자 선택 및 교육, 치료 압력의 적정성과 정기적 추적 관찰이 필요하다. ${ }^{7}$ 특히, 처음 수주간은 양압기 장기 사용에 있어 중요한 시기이므로 단기간 추적 관찰을 통한 면밀한 감 시가 중요하다. 이후 정기적이고 지속적인 추적 관찰을 함으 로써 장기간 사용을 유지할 수 있다. 양압기 사용 시간을 객관 적으로 점검하고 효과 및 불편함, 폐쇄수면무호흡과 관련된 내과 질환의 발생 유무에 대한 평가가 필요하다(Fig. 1). 체중 감소 및 수술로 폐쇄수면무호흡 관련 증상이 없어졌다 하더

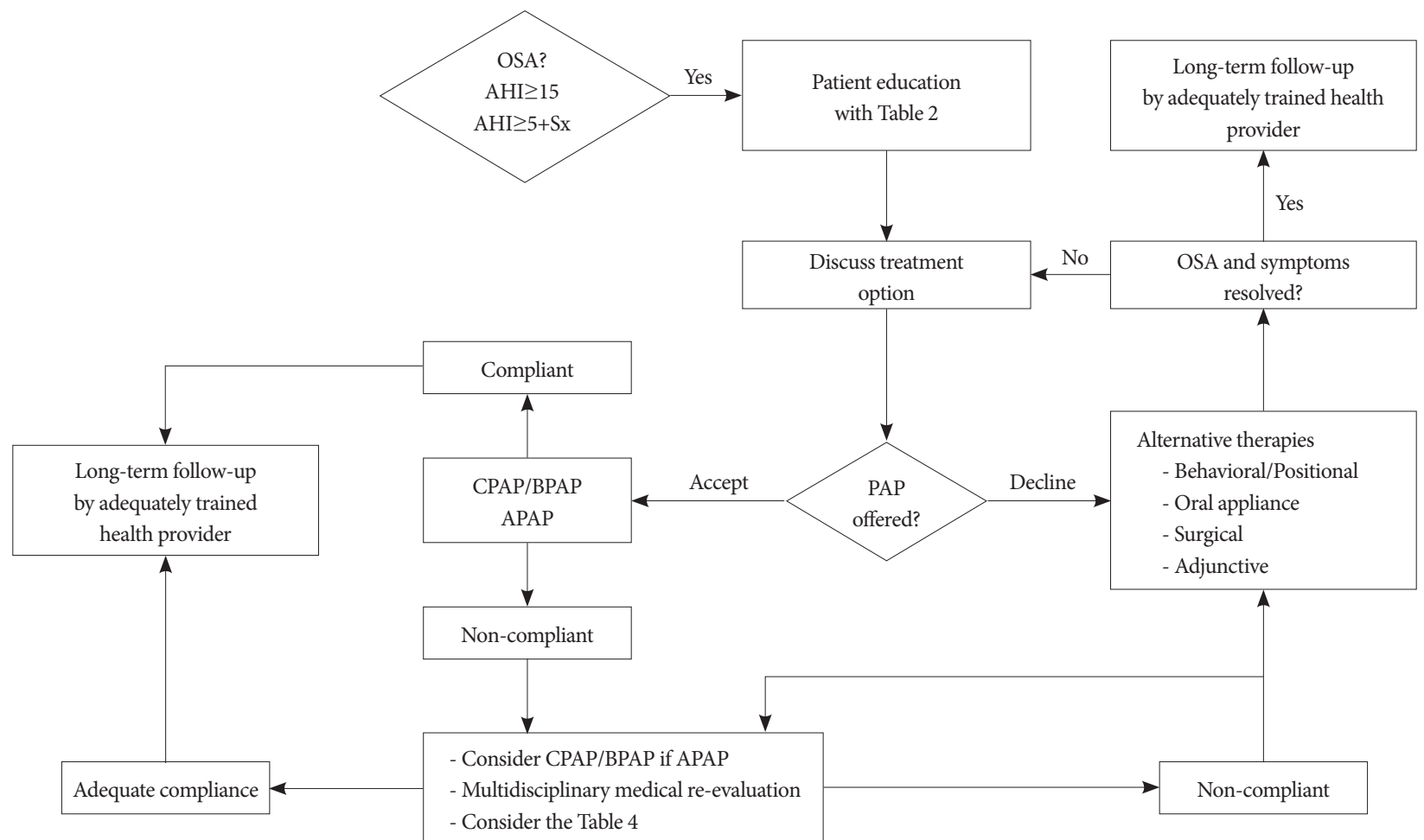

Figure 1. Procedure for management and follow-up of patients with obstructive sleep apnea. OSA: obstructive sleep apnea, AHI: apneahypopnea index, Sx: symptom, CPAP: continuous positive airway pressure, BPAP: bilevel positive airway pressure, APAP: auto-titrating positive airway pressure. 
라도 체중 조절, 금주, 금연과 같은 생활 습관 개선을 잘 유 지하도록 지속적으로 교육하고 증상이 재발 유무를 정기적 으로 추적 관찰한다. 증상이 지속되거나 순응도가 낮은 경우 는 마스크 유형, 가습 정도, 양압 ramp 시간, 양압기 종류, 동 반된 치과 및 이비인후과 문제를 점검하여 재조정한다. 주간 졸림이 지속되는 경우는 적정 압력 선택, 환자의 평소 수면 시간, 마스크를 통한 공기 유출과 동반된 기타 수면장애 등을 점검한다(Table 4). 양압기 사용 초기에는 효과를 보았으나 이후 주간졸림이 재발하는 경우는 체중 증가, 수면위생 저 하, 우울, 비염과 같은 이비인후과 문제 발생과 양압기 사용 초기의 위약 효과의 소실 등을 고려할 수 있다. ${ }^{42}$

\section{수술적 치료(surgical treatment)}

폐쇄수면무호흡의 수술적 치료는 상기도 부위에 따라 다 양한 방법이 있다(Table 5). 수술적 치료에 대한 AASM 권 고사항은 다음과 같다. ${ }^{43}$ 1) 수술적 치료 전에 폐쇄수면무호 흡 여부 및 중증도를 평가해야 한다(standard). 2) 환자에게 수술적 치료의 성공률과 합병증 발생 위험도, 대체 가능한 치료 방법(지속양압기, 구강 내 장치 등) 여부에 대한 충분한

Table 4. Considerations for non-compliant following PAP treatment

\begin{tabular}{l} 
Machine/interface \\
Mask fit \\
Humidification \\
Ramp \\
Repair \\
Alternative PAP modality \\
Medical \\
Sinus and hear problem \\
Nasal congestion \\
Anxiety/phobia \\
Negative social aspects \\
Residual sleepiness \\
Ensure duration of sleep is adequate \\
Confirm diagnosis of OSA \\
Confirm adequate CPAP/BPAP titration \\
Measure CPAP/BPAP efficacy at home to detect leaks, \\
measure compliance \\
Ensure adequate compliance \\
Exclude comorbid conditions causing EDS, detailed clinical \\
history, rule out depression, narcolepsy and poor sleep hygiene \\
Note that the patient may have experienced an unrealistic \\
degree of improvement at the start of CPAP/BPAP \\
\hline PAP:posiveairaypressre, OSA: obstrctive slep apnea, CPAP:
\end{tabular}

PAP: positive airway pressure, OSA: obstructive sleep apnea, CPAP: continuous positive airway pressure, BPAP: bilevel positive airway pressure, EDS: excessive daytime sleepiness
정보를 제공해야 한다(standard). 3) 수술적 치료의 목표는 폐쇄수면무호흡의 임상 증상 및 징후의 호전 및 수면의 질, $\mathrm{AHI}$, 산소포화도 수치의 정상화이다(standard). 4) 수술 방 법과 관련하여, 기관절개술(tracheostomy)은 폐쇄수면무호 흡의 효과적인 치료 방법이다. 하지만, 기관절개술은 다른 치 료 옵션이 존재하지 않거나, 과거에 실패했거나, 환자가 거부 했거나, 또는 의학적으로 응급한 이유로 기관절개술이 필요 한 경우에만 고려되어야 한다(option). 5) 양악전진술(maxillo-mandibular advancement)은 중증 폐쇄수면무호흡 환자 중에서 양압기 치료를 유지하지 못하는 경우 혹은 구강 내 장 치가 효과적이지 않거나 거부한 경우에 고려할 수 있다(option). 6) 목젖입천장인두성형술(uvulopalatopharyngoplasty) 은 중등도 및 중증 폐쇄수면무호흡에서 $\mathrm{AHI}$ 를 확실하게 정 상화시키지 못한다. 따라서 중증 폐쇄수면무호흡 치료로 먼 저 양압기를 고려해야 하며, 중등도 폐쇄수면무호흡 치료는 양압기 혹은 구강 내 장치 중 하나를 고려해야 한다(option). 비록 목젖입천장인두성형술이 일부 환자들에게서 더 편하 고 바람직한 치료 방법으로 보여질 수 있으나, 양압기 혹은 구 강 내 장치와 같은 효과가 증명된 치료 방법을 보다 먼저 고 려해야 한다.

\section{보조 요법(adjunctive therapies)}

비만 수술(bariatric surgery)은 보다 많은 체중 감소에 효과 적인 치료 방법으로, 체질량 지수(body mass index)가 $40 \mathrm{~kg} / \mathrm{m}^{2}$ 이상이거나 $35 \mathrm{~kg} / \mathrm{m}^{2}$ 이상이면서 주된 동반 질환이 있는 비 만 환자에서 체중 감량을 위한 식이 요법이 효과적이지 않 은 경우가 비만 수술의 적응증에 해당한다. ${ }^{44}$ 또한 비만 수술 은 비만 환자에서 폐쇄수면무호흡의 치료에 보조 요법으로 사용될 수 있다(option). ${ }^{12}$ 비만 수술은 덜 침습적이고 보다 효 과가 빠르게 나타나는 양압기와 같은 일차 치료의 보조 요법 으로 고려되어야 하며, 대상자는 폐쇄수면무호흡이 진단되고 동시에 비만 수술의 적응증에 해당되어야 한다(consensus).

폐쇄수면무호흡에 효과적인 약물 치료는 없지만, 갑상선 기능저하증이나 말단비대증과 같은 내과적 질환에 의한 경 우는 기저 질환에 대한 치료를 통해 $\mathrm{AHI}$ 를 호전시킬 수 있다.5 약물 치료로서 선택적 세로토닌 재흡수 억제제(selective serotonergic uptake inhibitors) (standard), protriptyline (guideline), methylxanthine 유도체(standard), 에스트로겐 치료(standard)는 폐쇄수면무호흡 치료로 권고되지 않는다. 단기작용성 비충혈제거제도 폐쇄수면무호흡 치료 방법으로 권고 되지 않지만(option), 국소적 비강 내 스테로이드는 비염이 동 반된 폐쇄수면무호흡 환자에서 $\mathrm{AHI}$ 를 호전시킬 수 있기 때 문에 보조적인 치료 방법으로 활용될 수 있다(guideline). ${ }^{12}$ 
Table 5. Common surgical procedures for obstructive sleep apnea by site

Upper airway bypass procedure

Nasal procedure

Oral, oropharyngeal, and nasopharyngeal procedures

Hypopharyngeal procedures

Laryngeal procedures

Global airway procedures

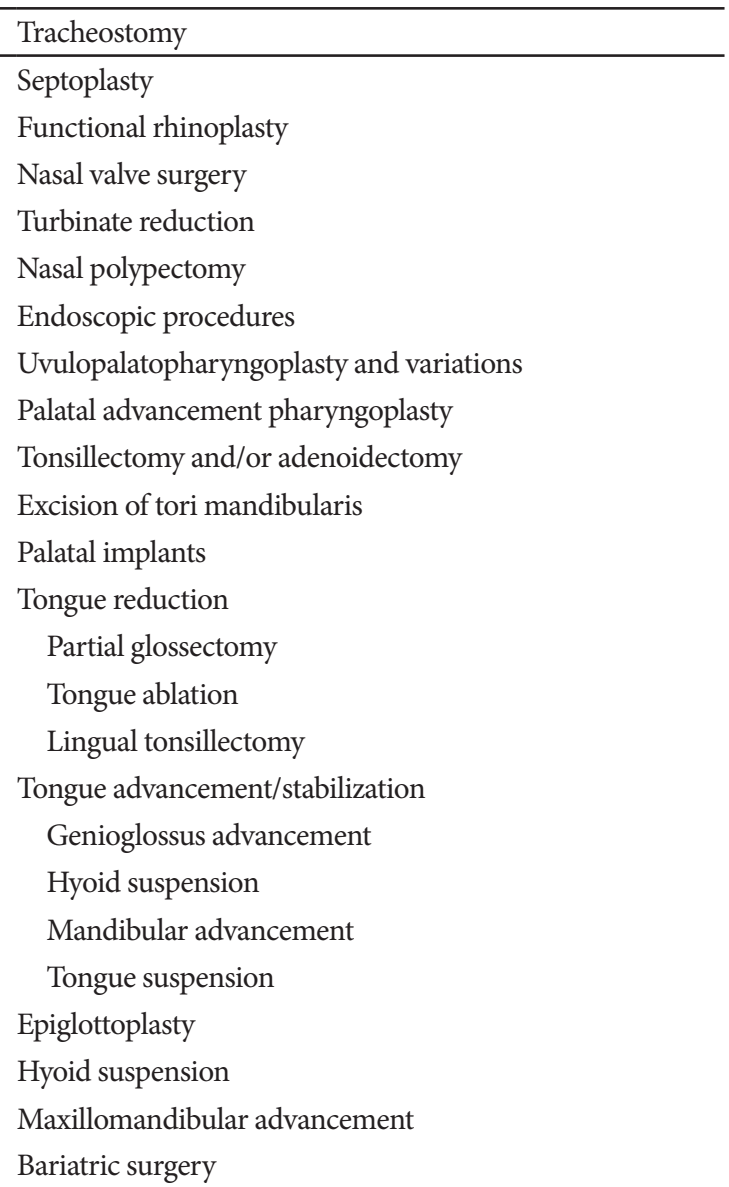

산소 보충 요법은 폐쇄수면무호흡의 일차 치료로 권고되 지 않는다(option). ${ }^{12}$ 만일 산소 보충이 저산소혈증(hypoxemia)을 교정하기 위한 보조 요법으로 사용된다면, 추적 검 사를 통해서 저산소혈증의 호전이 확인되어야 한다(consensus). 호흡기 질환이 동반된 환자에서 산소 보충 요법을 단독으로 사용하면 야간 저산소혈증은 줄일 수 있으나 무호 흡을 연장시키고 야간 고탄산혈증(hypercapnia)을 악화시킬 수 있다. ${ }^{46}$

\section{결 론}

폐쇄수면무호흡의 치료는 장기적이고 종합적인 관리를 요하는 만성질환의 치료 관점에서 이뤼져야 한다. 환자에게 폐쇄수면무호흡 치료의 중요성 및 필요성에 대한 충분한 교 육이 우선되어야 한다. 폐쇄수면무호흡의 일차적인 치료법 으로 양압기가 대표적이며, 만일 양압기 치료가 불가능하거 나 적합하지 않은 경우에 행동 요법, 구강 내 장치, 수술적 치 료와 보조 요법 등을 고려할 수 있다. 실제 임상에서 환자에 게 최적화된 치료를 제공하기 위해서 각 치료 방법별 적응
증과 금기 및 권고사항을 숙지할 필요가 있다.

\section{REFERENCES}

1. Kim J, In K, Kim J, et al. Prevalence of sleep-disordered breathing in middle-aged Korean men and women. Am J Respir Crit Care Med 2004;170:1108-1113.

2. Young T, Peppard PE, Gottlieb DJ. Epidemiology of obstructive sleep apnea: a population health perspective. Am J Respir Crit Care Med 2002; 165:1217-1239.

3. American Academy of Sleep Medicine. International classification of sleep disorders. 3rd ed. Darien: American Academy of Sleep Medicine, 2014.

4. Marin JM, Carrizo SJ, Vicente E, Agusti AG. Long-term cardiovascular outcomes in men with obstructive sleep apnoea-hypopnoea with or without treatment with continuous positive airway pressure: an observational study. Lancet 2005;365:1046-1053.

5. Engleman HM, Douglas NJ. Sleep. 4: sleepiness, cognitive function, and quality of life in obstructive sleep apnoea/hypopnoea syndrome. Thorax 2004;59:618-622.

6. Gay P, Weaver T, Loube D, et al. Evaluation of positive airway pressure treatment for sleep related breathing disorders in adults. Sleep 2006; 29:381-401.

7. Epstein LJ, Kristo D, Strollo PJ Jr, et al. Clinical guideline for the evaluation, management and long-term care of obstructive sleep apnea in adults. J Clin Sleep Med 2009;5:263-276.

8. Sullivan CE, Issa FG, Berthon-Jones M, Eves L. Reversal of obstructive sleep apnoea by continuous positive airway pressure applied through 
the nares. Lancet 1981;1:862-865.

9. Kushida CA, Chediak A, Berry RB, et al. Clinical guidelines for the manual titration of positive airway pressure in patients with obstructive sleep apnea. J Clin Sleep Med 2008;4:157-171.

10. Peppard PE, Young T, Palta M, Dempsey J, Skatrud J. Longitudinal study of moderate weight change and sleep-disordered breathing. JAMA 2000;284:3015-3021.

11. Kajaste S, Brander PE, Telakivi T, Partinen M, Mustajoki P. A cognitive-behavioral weight reduction program in the treatment of obstructive sleep apnea syndrome with or without initial nasal CPAP: a randomized study. Sleep Med 2004;5:125-131.

12. Morgenthaler TI, Kapen S, Lee-Chiong T, et al. Practice parameters for the medical therapy of obstructive sleep apnea. Sleep 2006;29:10311035.

13. Scrima L, Broudy M, Nay KN, Cohn MA. Increased severity of obstructive sleep apnea after bedtime alcohol ingestion: diagnostic potential and proposed mechanism of action. Sleep 1982;5:318-328.

14. Atwood Jr CW, Strollo Jr PJ, Givelber R. Medical therapy for obstructive sleep apnea. In: Kryger MH, Roth T, Dement WC. Principles and practice of sleep medicine. 5th ed. St. Louis: Saunders, 2011;1219-1232.

15. Wetter DW, Young TB, Bidwell TR, Badr MS, Palta M. Smoking as a risk factor for sleep-disordered breathing. Arch Intern Med 1994;154: 2219-2224.

16. Pevernagie DA, Stanson AW, Sheedy PF 2nd, Daniels BK, Shepard JW Jr. Effects of body position on the upper airway of patients with obstructive sleep apnea. Am J Respir Crit Care Med 1995;152:179-185.

17. Cartwright RD. Effect of sleep position on sleep apnea severity. Sleep 1984;7:110-114.

18. Jokic R, Klimaszewski A, Crossley M, Sridhar G, Fitzpatrick MF. Positional treatment vs continuous positive airway pressure in patients with positional obstructive sleep apnea syndrome. Chest 1999;115:771-781.

19. Kushida CA, Littner MR, Morgenthaler T, et al. Practice parameters for the indications for polysomnography and related procedures: an update for 2005. Sleep 2005;28:499-521.

20. Ferguson KA, Cartwright R, Rogers R, Schmidt-Nowara W. Oral appliances for snoring and obstructive sleep apnea: a review. Sleep 2006; 29:244-262.

21. Marklund M, Franklin KA, Sahlin C, Lundgren R. The effect of a mandibular advancement device on apneas and sleep in patients with obstructive sleep apnea. Chest 1998;113:707-713.

22. Kushida CA, Morgenthaler TI, Littner MR, et al. Practice parameters for the treatment of snoring and obstructive sleep apnea with oral appliances: an update for 2005. Sleep 2006;29:240-243.

23. Kushida CA, Littner MR, Hirshkowitz M, et al. Practice parameters for the use of continuous and bilevel positive airway pressure devices to treat adult patients with sleep-related breathing disorders. Sleep 2006;29:375-380.

24. Stepanski EJ. The need for a standardized CPAP titration protocol and follow-up procedures. J Clin Sleep Med 2005;1:311.

25. Jenkinson C, Davies RJ, Mullins R, Stradling JR. Comparison of therapeutic and subtherapeutic nasal continuous positive airway pressure for obstructive sleep apnoea: a randomised prospective parallel trial. Lancet 1999;353:2100-2105.

26. Pepperell JC, Ramdassingh-Dow S, Crosthwaite N, et al. Ambulatory blood pressure after therapeutic and subtherapeutic nasal continuous positive airway pressure for obstructive sleep apnoea: a randomised parallel trial. Lancet 2002;359:204-210.

27. Weinstock TG, Wang X, Rueschman M, et al. A controlled trial of CPAP therapy on metabolic control in individuals with impaired glucose tolerance and sleep apnea. Sleep 2012;35:617-625B.

28. Milleron O, Pillière R, Foucher A, et al. Benefits of obstructive sleep apnoea treatment in coronary artery disease: a long-term follow-up study. Eur Heart J 2004;25:728-734.
29. Kaneko Y, Floras JS, Usui K, et al. Cardiovascular effects of continuous positive airway pressure in patients with heart failure and obstructive sleep apnea. N Engl J Med 2003;348:1233-1241.

30. Barbé F, Durán-Cantolla J, Sánchez-de-la-Torre M, et al. Effect of continuous positive airway pressure on the incidence of hypertension and cardiovascular events in nonsleepy patients with obstructive sleep apnea: a randomized controlled trial. JAMA 2012;307:2161-2168.

31. Parra O, Sánchez-Armengol A, Bonnin M, et al. Early treatment of obstructive apnoea and stroke outcome: a randomised controlled trial. Eur Respir J 2011;37:1128-1136.

32. Bravata DM, Concato J, Fried T, et al. Continuous positive airway pressure: evaluation of a novel therapy for patients with acute ischemic stroke. Sleep 2011;34:1271-1277.

33. George CF. Reduction in motor vehicle collisions following treatment of sleep apnoea with nasal CPAP. Thorax 2001;56:508-512.

34. Mortimore IL, Kochhar P, Douglas NJ. Effect of chronic continuous positive airway pressure (CPAP) therapy on upper airway size in patients with sleep apnoea/hypopnoea syndrome. Thorax 1996;51:190-192.

35. Littner M, Hirshkowitz M, Davila D, et al. Practice parameters for the use of auto-titrating continuous positive airway pressure devices for titrating pressures and treating adult patients with obstructive sleep apnea syndrome. An American Academy of Sleep Medicine report. Sleep 2002;25:143-147.

36. Berry RB, Parish JM, Hartse KM. The use of auto-titrating continuous positive airway pressure for treatment of adult obstructive sleep apnea. An American Academy of Sleep Medicine review. Sleep 2002;25:148-173.

37. Collop NA, Anderson WM, Boehlecke B, et al. Clinical guidelines for the use of unattended portable monitors in the diagnosis of obstructive sleep apnea in adult patients. Portable Monitoring Task Force of the American Academy of Sleep Medicine. J Clin Sleep Med 2007;3: 737-747.

38. Morgenthaler TI, Aurora RN, Brown T, et al. Practice parameters for the use of autotitrating continuous positive airway pressure devices for titrating pressures and treating adult patients with obstructive sleep apnea syndrome: an update for 2007. An American Academy of Sleep Medicine report. Sleep 2008;31:141-147.

39. Ayas NT, Patel SR, Malhotra A, et al. Auto-titrating versus standard continuous positive airway pressure for the treatment of obstructive sleep apnea: results of a meta-analysis. Sleep 2004;27:249-253.

40. Ip S, D’Ambrosio C, Patel K, et al. Auto-titrating versus fixed continuous positive airway pressure for the treatment of obstructive sleep apnea: a systematic review with meta-analyses. Syst Rev 2012;1:20.

41. Patruno V, Aiolfi S, Costantino G, et al. Fixed and autoadjusting continuous positive airway pressure treatments are not similar in reducing cardiovascular risk factors in patients with obstructive sleep apnea. Chest 2007;131:1393-1399.

42. Santamaria J, Iranzo A, Ma Montserrat J, de Pablo J. Persistent sleepiness in CPAP treated obstructive sleep apnea patients: evaluation and treatment. Sleep Med Rev 2007;11:195-207.

43. Aurora RN, Casey KR, Kristo D, et al. Practice parameters for the surgical modifications of the upper airway for obstructive sleep apnea in adults. Sleep 2010;33:1408-1413.

44. SAGES Guidelines Committee. SAGES guideline for clinical application of laparoscopic bariatric surgery. Surg Obes Relat Dis 2009;5:387-405.

45. Veasey SC, Guilleminault C, Strohl KP, Sanders MH, Ballard RD, Magalang UJ. Medical therapy for obstructive sleep apnea: a review by the Medical Therapy for Obstructive Sleep Apnea Task Force of the Standards of Practice Committee of the American Academy of Sleep Medicine. Sleep 2006;29:1036-1044.

46. Berry RB, Light RW. Effect of hyperoxia on the arousal response to airway occlusion during sleep in normal subjects. Am Rev Respir Dis 1992;146:330-334. 